UDC 614.87

DOI: $10.21668 /$ health.risk/2021.3.04.eng

Review article

\title{
PREVENTIVE MEASURES TO REDUCE HARMFUL EFFECTS PRODUCED BY ELECTROMAGNETIC RADIATION ON HEALTH
}

\author{
Y. Stein ${ }^{1,2}$ \\ ${ }^{1}$ Faculty of Medicine, Hebrew University of Jerusalem, Campus Ein Kerem, Jerusalem, 9112102, Israel \\ ${ }^{2}$ Department of Anesthesiology, Critical Care and Pain Medicine, Hadassah Medical Center, Jerusalem, 91120, Israel
}

\begin{abstract}
Man-made electromagnetic waves are the most widely and rapidly expanding exposure in today's world, including exposure in several frequency groups: extremely low frequencies (ELF) from electricity lines, hybrid car batteries and high power lines $(>3 \mathrm{~Hz}-3 \mathrm{kHz})$, radiofrequency $(\mathrm{RF})$ and microwave frequencies including millimeter waves $(3 \mathrm{kHz}-300 \mathrm{GHz})$ from mobile phones, towers, base stations and wireless devices, and intermediate frequencies "Dirty Electricity" emitted from power lines.

While such organizations as ICNIRP (the International Commission on Non-Ionizing Radiation Protection) still continue to claim that electromagnetic radiation can cause "only thermal effects", clinging to theory that does not match facts and upholding obsolete thermal safety standards, extensive scientific evidence has clearly demonstrated that non-thermal health effects produced by electromagnetic radiation do exist, are important to health, and should be taken into consideration when safety standards are set. This review aims to highlight some evidence of biologic effects in various body systems, and to suggest preventive measures to reduce such effects on health.

Exposure to electromagnetic radiation at intensities lower than thermal safety standards has been associated with nonthermal biological effects including damage and changes to cells and DNA.

This review presents evidence of such effects demonstrated in: the hematologic system, the nervous system, the immune system, the reproductive system, the skin and muscles, the cardiovascular system, glucose metabolism, and electrohypersensitivity ("Microwave sickness"). Protective measures are then suggested to reduce these effects.

Key words: electromagnetic radiation, non-thermal exposure, health, electrohypersensitivity, protective measures, safety standards.
\end{abstract}

Exposure to electromagnetic radiation at intensities lower than thermal safety standards has been associated with non-thermal biological effects [1-3] including damage to cells and DNA and changes in them. This review focuses on providing evidence of such effects demonstrated in the hematologic, nervous, immune and reproductive systems, skin and muscles, cardiovascular system, glucose metabolism, and electrohypersensitivity ("microwave sickness"). Protective measures are then suggested to reduce these effects.

DNA effects. Lai and Singh [4] demonstrated an increase in DNA single and doublestrand breaks in brain cells of rats after two hours of exposure to $60 \mathrm{~Hz} \mathrm{ELF}$, and effect that could be blocked with melatonin and N-tert-butyl-a-phenylnitrone (PBN). Udroiu et al. [5] found significant increases in micronuclei in liver and peripheral blood samples from newborn mice that had been exposed inutero to ELF, $50 \mathrm{~Hz}, 650 \mathrm{mT}$ magnetic field. Zothansiama et al. [6] found significantly $(p<0.0001)$ higher frequency of micronuclei in the peripheral blood lymphocytes of people living within 80 meters from mobile base stations, compared to those living 300 meters away from the RF radiation source.

Hematologic system. Workers occupationally exposed to microwave radiation had hematological changes in peripheral blood in correlation with time of exposure [7]. Signifi-

(C) Stein Y., 2021

Yael Stein - a resident physician and researcher at the department of anesthesiology (e-mail: yael.stein1@mail.huji.ac.il; tel.: +972-50-3310121; ORCID: https://orcid.org/0000-0001-7915-1853). 
cant changes were seen in concentration and/or activity of glutathione (GSH), catalase (CAT) and superoxide dismutase (SOD) and rise in lipid peroxidation (LOO) in peripheral blood lymphocytes of people living near cellphone base stations [6]. Lai [8] reviewed and summarized multiple studies that showed changes in levels of free radical activities such as oxygen (ROS) / nitrogen (RNS) species and endogenous antioxidant enzymes following exposure to EMF.

Nervous system. Kim et al. [9] discussed many effects seen in the nervous system, including neuronal cell apoptosis, changes in nerve myelin and in ion channels. Sheppard et al. [10] discussed the calcium-efflux effect in chick brain tissue, in specific frequency and amplitude windows of exposure to EMF. Eberhardt et al. [11] demonstrated effect produced by RF $900 \mathrm{MHz}$ on rat blood brain barrier permeability and neuronal damage. Carruba et al. [12] demonstrated experimentally that low-frequency pulse by mobile phones triggered EEG evoked potentials in human volunteers. Effects produced by ELF on neurodegenerative diseases were shown by Benassi et al. [13] regarding Parkinson's disease, with significantly impaired redox homeostasis and thiol content in SH-SY5Y cells, and an increase in protein carbonylation; and by Bobkova et al. [14] with changes in spatial memory and brain amyloid- $\beta$ in two animal models of Alzheimer's disease. A review by Terzi et al. [15] summarizes additional neurodegenerative effects. In children, ADHD symptoms were associated with higher use of cell phone [16]. Many health risks associated with exposure to Wi-Fi [17] as well as neuropsychiatric effects produced by EMF exposure are summarized by Pall [18].

Immune system. Szmigielski [19] conducted a literature review and concluded that "short-term exposure to weak RF radiation may temporarily stimulate certain humoral or cellular immune functions, while prolonged irradiation inhibits the same functions". El-Gohary \& Said [20] reported effects produced by mobile phone RF EMF on immu- noglobulin levels (IgA, $\operatorname{IgE}, \operatorname{IgM}$, and $\operatorname{IgG}$ ); and on total leukocyte, lymphocyte, eosinophil, basophil, neutrophil and monocyte counts. Electrosmog effects on Vitamin-D receptor (VDR) and 1,25-dihydroxyvitamin-D (1,25-D), which are associated with many chronic inflammatory and autoimmune diseases are discussed by Marshall and Heil [21]. Lushnikov et al. [22] showed that under multiple repeated exposures, low-intensity extremelyhigh-frequency electromagnetic radiation (frequency of $42.0 \mathrm{GHz}$ and energy flux density of $0.15 \mathrm{~mW} / \mathrm{cm}^{2}$ for 20 minutes daily) affected immunogenesis in mice. Belpomme \& Irigaray [23] many of the patients had lowgrade inflammation and an autoimmune response involving autoantibodies against O-myelin, and in $80 \%$ of the patients with Electrohypersensitivity, several oxidative stress biomarkers were detected in peripheral blood.

Reproduction. Saygin et al. [24] reported pathophysiological changes in the testes of rats exposed to wireless frequencies $(2.45 \mathrm{GHz})$ for 3 hours per day. Schauer \& Mohamad AlAli [25] demonstrated that men who regularly carried mobile phones in trouser pockets showed higher percentage of pathologic morphology of sperm and lower levels of luteinizing hormone.

Skin. Johansson [26, 27] was one of the first to publish research papers about "screen dermatitis", an effect produced by EMF exposure on the skin reporting an increase in mast cells in facial skin samples of electrohypersensitive persons under long-term exposure. Cardona-Hernández et al. [28] reviewed some of the effects. Short-term skin exposure induces only a transient alteration of epidermal homoeostasis, but it may still alter the protective capacity of the skin [29]. Esen \& Esen [30] found lengthened latency of facial $\&$ head skin resistance response by approximately $200 \mathrm{~ms}$ following cell phone exposure. Belpomme \& Irigaray [23] demonstrated cutaneous lesions, mostly on the hands patients, and particularly on the hand which held a mobile phone. Feldman et al. [31] demonstrated that coiled sweat glands acted 
similarly to arrays of helical antennas, with a resonating frequency in the $\mathrm{THz}$ range that influenced RF-energy absorption of millimeter and submillimeter waves into human skin.

Muscle. Blank [32] discussed changes in biosynthetic patterns in muscle cells exposed to EMF stimuli that were similar to changes caused by other known stresses, such as heat shock. McCarty et al. [33] demonstrated muscle twitches in respond to changes (on/off) in EMF exposure.

Cardiovascular system. Vangelova et al. [34] assessed long-term effects of occupational EMF exposure on the cardiovascular system and found that the radiofrequency EMR exposure was associated with greater risk of hypertension and dyslipidemia. Another occupational study by Wilen et al. [35] compared RF operators with unexposed workers and showed that time integrated exposure parameters were of some importance regarding symptoms such as fatigue, headaches, and warmth sensations in the hands, and that RF operators had lower heart rate and more episodes of Bradycardia.

Rats exposed to high-power microwave RF had lower heart rate than non- exposed $\left(30 \mathrm{~mW} / \mathrm{cm}^{2}\right.$ for $15 \mathrm{~min}$ - this is a very high exposure but the point is to demonstrate pathological changes in the myocardium). Exposed rats demonstrated histological and ultrastructural changes in the myocardium, with swollen and irregularly arranged myocytes, and some chromatin condensation with dark staining in nuclei [36].

My colleagues and I demonstrated severe and unique vascular calcification in the aortas of rats exposed to intermediate frequencies of $150-155 \mathrm{kHz}$ in an animal model of chronic kidney disease. We thought that an irradiating device could remove calcium from cardiac valves, but the result was the opposite [37]. We repeated this study with ELF exposure to $50 \mathrm{~Hz}$ using cell phone chargers and found the same results but the data were not published. Two long-term RF exposure studies performed at the Ramazzini Institute and by the US Department of Health and Human Services National Toxicology Program (NTP) found clear evidence of an association between long-term low-intensity RF EMF exposure and tumors in the hearts (and brains) of male rats [38, 39].

Glucose \& metabolism. Meo \& Al Rubeaan [40] compared groups of rats exposed to mobile phone radiation. The rats that were exposed for longer than $15 \mathrm{~min} /$ day for a 3 months had higher fasting blood glucose $(p<0.015)$ and serum insulin $(p<0.01)$ compared to unexposed and their insulin resistance was significantly increased $(p<0.003)$ compared to control rats. Ben Salah et al. [41] exposed rats to $\mathrm{Wi}-\mathrm{Fi}(2.4 \mathrm{GHz})$ and noted an alternation in blood glucose level between hypo- and hyperglycaemia during 21 days that the rats were exposed to Wi-Fi, compared to the unexposed group. The exposed rats had an increase in plasma total proteins, triglycerides, creatinine, ALAT, ASAT and iron levels and decrease in plasma uric acid.

Electrohypersensitivity (EHS), formerly known as "Microwave sickness". Most of the symptoms described by electrohypersensitive patients are a consequence of neural damage and over-sensitized neural responses [42]. Belpomme \& Irigaray [43] showed an overlap between Multiple Chemical Sensitivity and Electrohypersensitivity in about $30 \%$ of their large database on over than 2,000 patients. The patients' typical symptoms were: "headache, tinnitus, hyperacusis, dizziness, balance disorder, superficial and/or deep sensibility abnormalities, fibromyalgia, vegetative nerve dysfunction, and reduced cognitive capability, including immediate memory loss, attentionconcentration deficiency, and eventually tempospatial confusion. These symptoms were associated with chronic insomnia, fatigue, and depressive tendency, in addition to emotional lability and sometimes irritability".

In an extensive study performed on one electrohypersensitive patient, McCarty et al. [33] demonstrated that within 100 seconds after initiation of EMF exposure $(p<0.05)$ the patient developed somatic responses to the exposure, including neural symptoms: temporal pain, headache; muscular symptoms: muscle twitching; and cardiovascular symptoms: skipped 
heartbeats. The symptoms appeared following field transitions (off-on, on-off) rather than induced by the mere presence of the field. The patient was not able to consciously identify when the electromagnetic field was turned on or off.

Mechanistic studies. Many mechanistic studies have described the non-thermal interactions between electromagnetic fields and biological tissues [43]. Blackman et al. [44] presented the concept of multiple powerdensity windows. Liboff [45] discussed resonance effects. Panagopoulos et al. [46] suggested that an external oscillating field vibrating freed ions on the surface of a cell plasma membrane and irregularly gated electrosensitive channels on the plasma membrane disrupting the cell's electrochemical balance and function. Friedman et al. [47] proposed a mechanism of short-term ERK activation by RF frequencies. Giuliani et al. [48] researched the "Zhadin current", coherent excitations in mesoscopic regions of ions and biomolecules, that gave rise to electric currents and consequent magnetic fields in a cell, and Zhadin [49] analyzed Quantum mechanisms to further explain these effects. Blank and Goodman [50] demonstrated that DNA expressed two structural characteristics of a fractal antenna in an electromagnetic field, electronic conduction and self-symmetry.

Results. Based on the presented evidence presented that health effects from exposure to chronic exposure, low levels of EMF exist, the following Preventive \& Protective Measures are adapted from Recommendations published by international scientist groups; medical organizations; environmental protection and selfhelp activist groups. Many of these groups have called for lowering allowed EMF exposure levels and halting plans to expand exposure with 5G networks [51-63].

An increase in distance and use reduction are important factors to reduce exposure and consequent health risks. Proximity is the most important factor in exposure. Radiation levels fall dramatically with distance from the source.

A. The public realm. Figure 1 presents a comparison between allowed exposure limits to RF radiation (including from cell towers) in various countries. Reduction of exposure from cell phone towers / antennas is technically possible and is carried out in some countries better than in others. Keeping long distance from kindergartens and schools is extremely important, since children are a more susceptible population to any environmental exposure; and distancing antennas from bedrooms, to avoid unnecessary and harmful exposure during sleep.

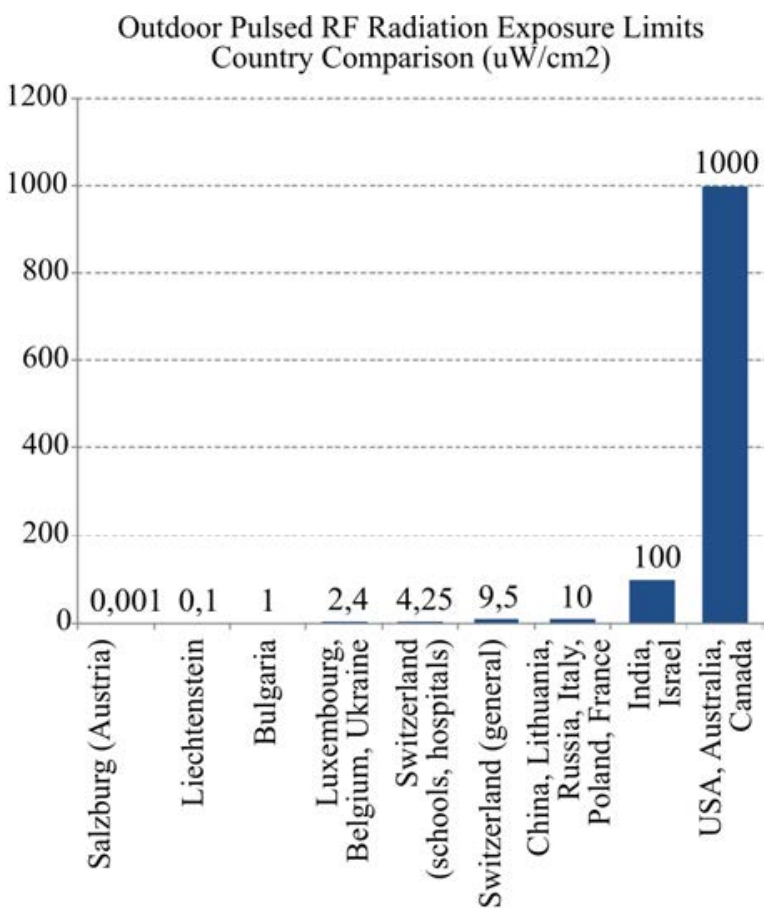

Figure 1. Country comparison. Outdoor Pulsed RF EMF exposure limits, $\mathrm{uW} / \mathrm{cm}^{2}$

Wireless utility meters and wireless devices in the public realm, while perhaps emitting low mean intensity levels of EMF, emit biologically important pulsed exposure that is more harmful, even at low measured intensities. Furthermore, EMF intensity measurements are often incorrect if performed using

\footnotetext{
${ }^{1}$ Copyright Environmental Health Trust; reproduced with permission.
} 


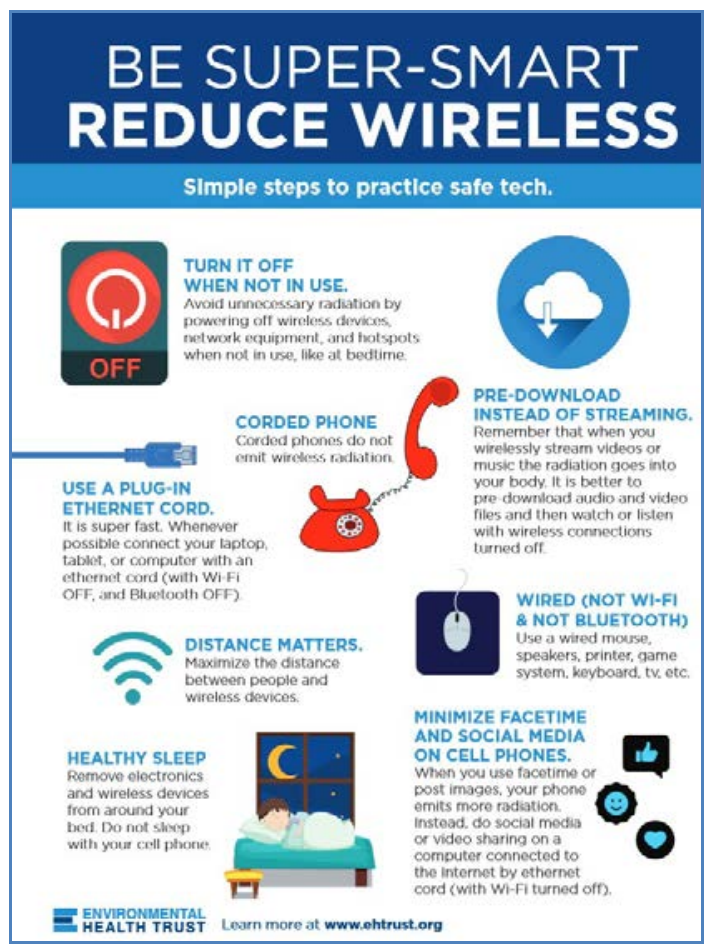

Figure 2. Ways to reduce Cellphone radiation from wireless devices ${ }^{1}$

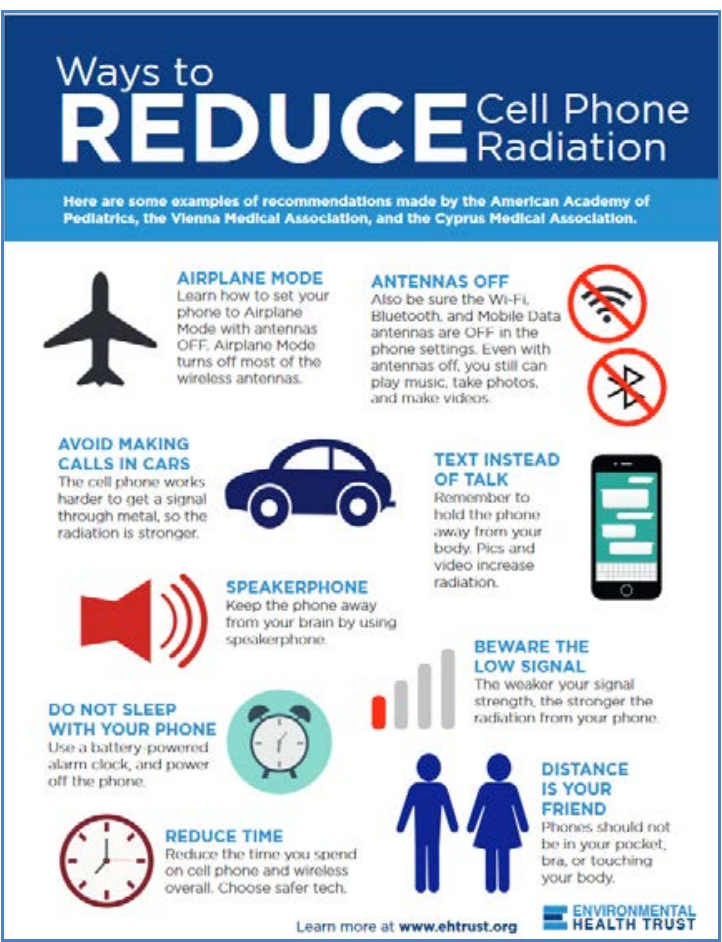

Figure 3. Ways to reduce exposure ${ }^{1}$

Figure 4. How to hardwire your mobile device ${ }^{1}$

Figure 5. Reduce computer EMF exposure ${ }^{1}$ 
a measurement device that does not have the adequate measurement speed [64].

Avoid use of Wi-Fi at school - always prefer safer wired technology that does not emit RF EMF.

B. Exposure from personal devices. The most extensive and problematic exposure comes from use of personal devices since they are closer to a body. Devices that emit pulsed waves are especially harmful even if the exposure intensity is not high. Figures 2-5 present exposure reduction strategies developed by the Environmental Health Trust and presented here with permission.

Recommendations on preventing health symptoms from EMF exposure. Distance wireless devices from your body:

- Avoid carrying cell phone on your body at all times. Reproductive organs, especially in pregnancy; the nervous system; and cardiovascular system are sensitive.

- When talking or texting, position the cell phone away from your body as far as possible, use speaker or an "air tube" wired headset (not Bluetooth).

- Avoid placing cordless home phones near you, especially when sleeping.

- Do not place a laptop or tablet device on your lap since these devices emit Radio Frequency radiation (RF EMF) like cell phones; it is especially important during pregnancy.

- Do not place a powered cell phone near you while you sleep.

body.

- Do not charge a cell phone near your

Reduce use of emitting wireless devices in your home:

- Prefer use of corded home phones that do not emit RF radiation for most calls.

- Connect the internet router via Ethernet cables and turn off Wi-Fi.

- Use wired keyboard, mouse, etc.

- Turn Wi-Fi off when not in use (router and devices), especially at night.

- Turn off printers' Wi-Fi feature since printers continuously emit very high levels of RFR.
Minimize exposure:

- Minimize time of phone use. Prefer texting to long phone conversations.

- Reduce use of streamed media on the cell phone; whenever possible download the content and then access it on "airplane mode", with Wi-Fi and other modes (Bluetooth etc.) switched off, to reduce your exposure while handling the device.

- Children should only use cell phones for emergencies since cell phone radiation penetrates deeper into their brains.

- Avoid using cell phone inside spaces that are surrounded by metal, when the signal is weak, or when moving at high speed, for example in vehicles or elevators. The cell phone emits higher radiation because in such places it makes a greater effort to connect to the antenna, or to connect to changing distant antennas (when moving).

- Avoid charging laptops while in use. When charging, use a 3-pronged grounded cable [65].

Importance of this review. Health hazards caused by EMF exposure have not been adequately addressed by national and international organizations such as the World Health Organization [66-71]. It is necessary to reduce exposures to all frequencies of EMFs, according to the Precautionary Principle. Cellphone networks should be planned to emit reduced exposures - but global plans are only to expand exposure, on land and in space [70]. A recent study analyzed the expected exposure effects of planned G5 antenna density [72]. Calculating from known power consumption modeling, Ben Ishai [73] suggests that G5 networks would emit a 6-fold increased ambient radiation compared to current networks, and would require a thousand times as much electricity to power the networks.

Acknowledgements. The author thanks the Environmental Health Trust for graphics reproduction.

Funding. The research was not granted any financial support.

Conflict of interests. The author states no conflict of interests. 


\section{References}

1. Markov M. Thermal Vs. Nonthermal Mechanisms of Interactions Between Electromagnetic Fields and Biological Systems. Bioelectromagnetics Current Concepts. NATO Security Through Science Series. In: S.N. Ayrapetyan, M.S. Markov eds. Dordrecht, Springer, 2006, pp. 1-15. DOI: 10.1007/1-4020-4278-7_1

2. ICNIRP Guidelines for Limiting Exposure to Electromagnetic Fields (100 Khz To $300 \mathrm{ghz}$ ). Health Phys., 2020, vol. 118, no. 5, pp. 483-524. DOI: 10.1097/HP.0000000000001210

3. Belpomme D., Hardell L., Belyaev I., Burgio E., Carpenter D.O. Thermal and non-thermal health effects of low intensity non-ionizing radiation: An international perspective. Environmental Pollution, 2018, vol. 242, pt. A, pp. 643-658. DOI: 10.1016/j.envpol.2018.07.019

4. Lai H., Singh N.P. Melatonin and N-tert-butyl-alpha-phenylnitrone block $60-\mathrm{Hz}$ magnetic field-induced DNA single and double strand breaks in rat brain cells. J. Pineal Res, 1997, vol. 22, no. 3, pp. 152-162. DOI: 10.1111/j.1600-079x.1997.tb00317.x

5. Udroiu I., Cristaldi M., Ieradi L.A., Bedini A., Giuliani L., Tanzarella C. Clastogenicity and aneuploidy in newborn and adult mice exposed to $50 \mathrm{~Hz}$ magnetic fields. Int. J. Rad. Biol., 2006, vol. 82, no. 8, pp. 561-567. DOI: 10.1080/09553000600876660

6. Zothansiama, Zosangzuali M., Lalramdinpuii M., Jagetia G.C. Impact of radiofrequency radiation on DNA damage and antioxidants in peripheral blood lymphocytes of humans residing in the vicinity of mobile phone base stations. Electromagnetic Biology \& Medicine, 2017, vol. 36, no. 3, pp. 295-305. DOI: 10.1080/15368378.2017.1350584

7. Marino A.A. Time-dependent hematological changes in workers exposed to electromagnetic fields. Am. Ind. Hyg. Assoc. J., 1995, vol. 56, no. 2, pp. 189-192. DOI: 10.1080/15428119591017231

8. Lai H. Exposure to Static and Extremely-Low Frequency Electromagnetic Fields and Cellular Free Radicals. Electromagnetic Biology and Medicine, 2019, vol. 38, no 4, pp. 231-248. DOI: $10.1080 / 15368378.2019 .1656645$

9. Kim J.H., Lee J.-K., Kim H.-G., Kim K.-B., Kim H.R. Possible Effects of Radiofrequency Electromagnetic Field Exposure on Central Nerve System, Biomol. Ther., 2019, vol. 27, no. 3, pp. 265-275. DOI: $10.4062 /$ biomolther.2018.152

10. Sheppard A.R., Bawin S.M., Adey W.R. Models of long-range order in cerebral macromolecules: Effects of sub-ELF and of modulated VHF and UHF fields. Radio Science, 1979, vol. 14, no. 6S, pp. 141-145. DOI: 10.1029/RS014i06Sp00141

11. Eberhardt J.L., Persson B.R., Brun A.E., Salford L.G., Malmgren L.O. Blood-brain barrier permeability and nerve cell damage in rat brain 14 and 28 days after exposure to microwaves from GSM mobile phones. Electromagn. Biol. Med., 2008, vol. 27, no. 3, pp. 215-229. DOI: 10.1080/15368370802344037

12. Carrubba S., Frilot C. 2nd, Chesson A.L. Jr., Marino A.A. Mobile-phone pulse triggers evoked potentials. Neurosci. Lett., 2010, vol. 469, no. 1, pp. 164-168. DOI: 10.1016/j.neulet.2009.11.068

13. Benassi B., Filomeni G., Montagna C., Merla C., Lopresto V., Pinto R., Marino C., Consales C. Extremely Low Frequency Magnetic Field (ELF-MF) Exposure Sensitizes SH-SY5Y Cells to the Pro-Parkinson's Disease Toxin MPP (.). Mol. Neurobiol., 2016, vol. 53, no. 6, pp. 4247-4260. DOI: $10.1007 / \mathrm{s} 12035-015-9354-4$

14. Bobkova N.V., Novikov V.V., Medvinskaya N.I., Aleksandrova I.Y., Nesterova I.V., Fesenko E.E. Effect of weak combined static and extremely low-frequency alternating magnetic fields on spatial memory and brain amyloid- $\beta$ in two animal models of Alzheimer's disease. Electromagn. Biol. Med., 2018, vol. 37, no. 3, pp. 127-137. DOI: 10.1080/15368378.2018.1471700

15. Terzi M., Ozberk B., Deniz O.G., Kaplan S. The role of electromagnetic fields in neurological disorders. J. Chem. Neuroanat., 2016, vol. 7, pt. B, pp. 77-84. DOI: 10.1016/j.jchemneu.2016.04.003

16. Byun Y.-H., Ha M., Kwon H.-J., Hong Y.-C., Leem J.-H., Sakong J., Kim S.Y., Lee C.G. [et al.]. Mobile Phone Use, Blood Lead Levels, and Attention Deficit Hyperactivity Symptoms in Children: a longitudinal study. PLoS One, 2013, vol. 8, no. 3, pp. e59742. DOI: 10.1371/journal.pone.0059742

17. Pall M.L. Wi-Fi is an important threat to human health. Environmental Research, 2018, no. 164 , pp. 405-416. DOI: 10.1016/j.envres.2018.01.035 
18. Pall M.L. Microwave frequency electromagnetic fields (EMFs) produce widespread neuropsychiatric effects including depression. J. Chem. Neuroanat., 2016, vol. 75, pt. B, pp. 43-51. DOI: 10.1016/j.jchemneu.2015.08.001

19. Szmigielski S. Reaction of the immune system to low-level RF/MW exposures. Sci. Total. Environ., 2013, vol. 454-455, pp. 393-400. DOI: 10.1016/j.scitotenv.2013.03.034

20. El-Gohary O.A., Said M.A. Effect of electromagnetic waves from mobile phone on immune status of male rats: possible protective role of vitamin D. Can. J. Physiol. Pharmacol., 2017, vol. 95, no. 2, pp. 151-156. DOI: 10.1139/cjpp-2016-0218

21. Marshall T.G., Rumann Heil T.J. Electrosmog and autoimmune disease. Immunol. Res., 2017, vol. 65, no. 1, pp. 129-135. DOI 10.1007/s12026-016-8825-7

22. Lushnikov K.V., Gapeev A.B., Sadovnikov V.B., Chemeris N.K. Effect of the weak extremely-high-frequency electromagnetic radiation on the indices of the Humoral Immunity in healthy mice. Biophysics, 2001, vol. 46, no. 4, pp. 711-719.

23. Belpomme D., Irigaray P. Electrohypersensitivity as a Newly Identified and Characterized Neurologic Pathological Disorder: How to Diagnose, Treat, and Prevent It. Int. J. Mol. Sci., 2020, vol. 21, no. 6, pp. 1915. DOI: 10.3390/ijms21061915

24. Saygin M., Asci H., Ozmen O., Cankara F.N., Dincoglu D., Ilhan I. Impact of $2.45 \mathrm{GHz}$ microwave radiation on the testicular inflammatory pathway biomarkers in young rats: The role of gallic acid. Environ. Toxicol., 2016, vol. 31, no. 12, pp. 1771-1784. DOI: 10.1002/tox.22179

25. Schauer I., Mohamad Al-Ali B. Combined effects of varicocele and cell phones on semen and hormonal parameters. Wien Klin Wochenschr, 2018, vol. 130, pp. 335-340. DOI: 10.1007/s00508-017-1277-9

26. Johansson O., Hilliges M., Björnhagen V., Hall K. Skin changes in patients claiming to suffer from "screen dermatitis": a two-case open-field provocation study. Exp. Dermatol., 1994, vol. 3, no. 5, pp. 234-238. DOI: 10.1111/j.1600-0625.1994.tb00282.x

27. Johansson O., Liu P.-Y. "Electrosensitivity", "electrosupersensitivity" and "screen dermatitis": preliminary observations from on-going studies in the human skin. Proceedings of the COST 244: Biomedical Effects of Electromagnetic Fields. Workshop on Electromagnetic Hypersensitivity. In: D. Simunic ed. Brussels/Graz, EU/EC (DG XIII), 1995, pp. 52-57.

28. Cardona-Hernández M.A., Fierro-Arias L., Cabrera Pérez A.L., Vidal-Flores A.A. Efectos de la radiación electromagnética en la piel [Effects of electromagnetic radiation on skin]. Dermatol. Rev. Mex., 2017, vol. 61, no. 4, pp. 292-302 (in Spanish).

29. Simon D., Daubos A., Pain C., Fitoussi R., Vié K., Taieb A., de Benetti L., Cario-André M. Exposure to acute electromagnetic radiation of mobile phone exposure range alters transiently skin homeostasis of a model of pigmented reconstructed epidermis. Int. J. Cosmet. Sci., 2013, vol. 35, no. 1 , pp. 27-34. DOI: $10.1111 /$ j.1468-2494.2012.00746.x

30. Esen F., Esen H. Effect of electromagnetic fields emitted by cellular phones on the latency of evoked electrodermal activity. Int. J. Neurosci., 2006, vol. 116, no. 3, pp. 321-329. DOI: 10.1080/00207450500403371

31. Feldman Y., Puzenko A., Ishai P.B., Caduff A., Davidovich I., Sakran F., Agranat A.J. The electromagnetic response of human skin in the millimetre and submillimetre wave range. Phys. Med. Biol., 2009, vol. 54, no. 11, pp. 3341-3363. DOI: 10.1088/0031-9155/54/11/005

32. Blank M. Electric stimulation of protein synthesis in muscle. Advances in Chemistry, 1995, vol. 250, pp. 143-153. DOI: 10.1021/ba-1995-0250.ch009

33. McCarty D.E., Carrubba S., Chesson A.L., Frilot C., Gonzalez-Toledo E., Marino A.A. Electromagnetic hypersensitivity: evidence for a novel neurological syndrome. Int. J. Neurosci., 2011, vol. 121, no. 12, pp. 670-676. DOI: 10.3109/00207454.2011.608139

34. Vangelova K., Deyanov C., Israel M. Cardiovascular risk in operators under radiofrequency electromagnetic radiation. Int. J. Hyg. Environ. Health, 2006, vol. 209, no. 2, pp. 133-138. DOI: $10.1016 /$ j.ijheh.2005.09.008

35. Wilen J., Hornsten R., Sandstrom M., Bjerle P., Wiklund U., Stensson O., Lyskov E., Mild K.H. Electromagnetic field exposure and health among RF plastic sealer operators. Bioelectromagnetics, 2004, vol. 25, no. 1, pp. 5-15. DOI: 10.1002/bem.10154 
36. Zhang X., Gao Y., Dong J., Wang S., Yao B., Zhang J., Hu S., Xu X. [et al.]. The Compound Chinese Medicine "Kang Fu Ling" Protects against High Power Microwave-Induced Myocardial Injury. PLoS One, 2014, vol. 9, no. 7, pp. e101532. DOI: 10.1371/journal.pone.0101532

37. Shuvy M., Abedat S., Beeri R., Valitzki M., Stein Y., Meir K., Lotan C. Electromagnetic fields promote severe and unique vascular calcification in an animal model of ectopic calcification. Experimental and Toxicologic Pathology, 2014, vol. 66, no. 7, pp. 345-350. DOI: 10.1016/j.etp.2014.05.001

38. Falcioni L., Bua L., Tibaldi E., Lauriola M., De Angelis L., Gnudi F., Mandrioli D., Manservigi M. [et al.]. Report of final results regarding brain and heart tumors in Sprague-Dawley rats exposed from prenatal life until natural death to mobile phone radiofrequency field representative of a 1.8 GHz GSM base station environmental emission. Environ. Res., 2018, vol. 165, pp. 496-503. DOI: $10.1016 /$ j.envres.2018.01.037

39. NTP Technical Report on the Toxicology and Carcinogenesis Studies in Sprague-Dawley Rats Exposed to Whole-body Radio Frequency Radiation at a Frequency (900 Mhz) and Modulations (GSM and CDMA) Used by Cell Phones: Technical Report 595. National Toxicology Program. Public Health Service. U.S. Department of Health and Human Services, 2018. Available at: https://ntp.niehs.nih.gov/ntp/htdocs/lt_rpts/tr595_508.pdf?utm_source=direct\&utm_medium=prod\& utm_campaign=ntpgolinks\&utm_term $=\operatorname{tr} 595$ (05.06.2021).

40. Meo S.A., Rubeaan K.Al. Effects of exposure to electromagnetic field radiation (EMFR) generated by activated mobile phones on fasting blood glucose. Int. J. Occup. Med. Environ. Health, 2013, vol. 26, no. 2 , pp. 235-241. DOI: 10.2478/s13382-013-0107-1

41. Salah M.B., Abdelmelek H., Abderraba M. Effects of olive leave extract on metabolic disorders and oxidative stress induced by $2.45 \mathrm{GHz}$ WI-FI signals. Environ. Toxicol. Pharmacol., 2013, vol. 36, no. 3, pp. 826-834. DOI: 10.1016/j.etap.2013.07.013

42. Stein Y., Udasin I. Electromagnetic hypersensitivity (EHS, microwave syndrome) Review of mechanisms. Environmental Research, 2020, vol. 186, pp. 09445. DOI: 10.1016/ j.envres.2020.109445

43. Belyaev I. Biophysical Mechanisms for Nonthermal Microwave Effects. Electromagnetic Fields in Biology and Medicine (1st ed.). In: M.S. Markov ed. Boca Raton, CRC Press, 2015, Chapter 5, pp. 49-68.

44. Blackman C.F., Kinney L.S., House D.E., Joines W.T. Multiple power-density windows and their possible origin. Bioelectromagnetics, 1989, vol. 10, no. 2, pp. 115-128. DOI: 10.1002/bem2250100202

45. Liboff A.R. Geomagnetic cyclotron resonance in living cells. J. Biological. Phys., 1985, vol. 13 , no. 4 , pp. $99-102$.

46. Panagopoulos D.J., Karabarbounis A., Margaritis L.H. Mechanism for action of electromagnetic fields on cells. Biochemical and Biophysical Research Communications, 2002, vol. 298, no. 1, pp. 95-102. DOI: 10.1016/S0006-291X(02)02393-8

47. Friedman J., Kraus S., Hauptman Y., Schiff Y., Seger R. Mechanism of short-term ERK activation by electromagnetic fields at mobile phone frequencies. The Biochemical journal, 2007, vol. 405, no. 3, pp. 559-568. DOI: 10.1042/BJ20061653

48. Giuliani L., D’Emilia E., Grimaldi S., Lisi A., Bobkova N., Zhadin M.N. Investigating the Icr Effect in a Zhadin's Cell. Int. J. Biomed. Sci., 2009, vol. 5, no. 2, pp. 181-186.

49. Zhadin M. On mechanism of combined extremely weak magnetic field action on aquaeous solution of amino acid. Non-thermal effects and mechanisms of interaction between electromagnetic fields and living matter. ICEMS Monograph. Eur. J. Oncology, 2010, vol. 5, pp. 1-5.

50. Blank M., Goodman R. DNA is a fractal antenna in electromagnetic fields. Int. J. Radiat. Biol., 2011, vol. 87, no. 4, pp. 409-415. DOI: 10.3109/09553002.2011.538130

51. Guideline of the Austrian Medical Association for diagnosis and treatment of EMF-related health problems and illnesses (EMF Syndrome). Austrian Medical Association, 2012. Available at: https://vagbrytaren.org/Guideline\%20\%20AG-EMF.pdf (11.08.2021).

52. Belyaev I., Dean A., Eger H., Hubmann G., Jandrisovits R., Kern M., Kundi M., Moshammer H. [et al.]. EUROPAEM EMF Guideline 2016 for the prevention, diagnosis and treatment 
of EMF-related health problems and illnesses. Rev. Environ. Health, 2016, vol. 31, no. 3, pp. 363-397. DOI: $10.1515 /$ reveh-2016-0011

53. O rekomendatsiyakh roditelyam po bezopasnomu ispol'zovaniyu mobil'nogo telefona [Recommendations for parents on the safe use of a mobile phone]. Federal'naya sluzhba po nadzoru $\mathrm{v}$ sfere zashchity prav potrebitelei i blagopoluchiya cheloveka. Available at: https://www.rospotrebnadzor.ru/about/info/news/news_details.php?ELEMENT_ID=13375 (15.07.2021) (in Russian).

54. What you need to know about wireless radiation and your baby. The Baby Safe Project. Available at: https://128441a4-6b5e-4ac8-8d74-a461f5bada16.filesusr.com/ugd/2cea04_9747b215 cd62435aa100d3d331ab0673.pdf (04.06.2021).

55. Living with Technology, Children's Health Remains their Inexplicable Right and our Own Obligation: Press release 24 June 2019. Cyprus Committee on Environment and Children's Health. Available at: https://ehtrust.org/wp-content/uploads/PRESS-RELEASE-Cyprus-2019-Campaign-3.pdf (07.06.2021).

56. Mallery-Blythe E. 2020 Consensus Statement of UK and International Medical and Scientific Experts and Practitioners on Health Effects of Non-Ionising Radiation (NIR). Physicians' Health Initiative for Radiation and Environment (PHIRE) \& British Society for Ecological Medicine (BSEM). Available at: https://phiremedical.org/wp-content/uploads/2020/11/2020-Non-IonisingRadiation-Consensus-Statement.pdf (07.06.2021).

57. Switzerland Doctors For Environmental Protection. 2020 Consensus Statement of UK and International Medical and Scientific Experts and Practitioners on Health Effects of Non-Ionising Radiation (NIR). Available at: https://ehtrust.org/science/medical-doctors-consensus-statementsrecommendations-cell-phoneswireless/ (07.06.2021).

58. Cell Phone Radiation \& Children's Health: What Parents Need to Know. American academy of Pediatrics. Available at: https://www.healthychildren.org/English/safety-prevention/allaround/Pages/Cell-Phone-Radiation-Childrens-Health.aspx (08.06.2021).

59. 10 Years after the Freiburg Appeal: Radio-frequency Radiation Poses a Health Risk. Physicians Demand Overdue Precaution. International Doctors'Appeal 2012. Available at: http://freiburger-appell-2012.info/media/International_Doctors_Appeal_2012_Nov.pdf (17.05.2021).

60. Di Ciaula A. $5 \mathrm{G}$ networks in European Countries: appeal for a standstill in the respect of the precautionary principle. International Society of Doctors for Environment. Available at: https:// www.isde.org/5G appeal.pdf (14.06.2021).

61. The Venice Resolution. International commission for electromagnetic safety, 2008. Available at: http://www.icems.eu/resolution.htm (13.06.2021).

62. The Benevento Resolution. International Commission for Electromagnetic Safety, 2006. Available at: http://www.icems.eu/docs/BeneventoResolution_REVISED_march2008.pdf(13.06.2021).

63. Scientists call for Protection from Non-ionizing Electromagnetic Field Exposure: International Appeal. Available at: https://emfscientist.org/index.php/emf-scientist-appeal (20.06.2021).

64. Simunic D. Measurement of RF Near and Far Fields. WHO International Seminar on Biological Effects, Health Consequences and Standards for Pulsed Radiofrequency fields. Erice, November 21-30, 1999.

65. Step by step to safe technology. Environmental Health Trust. Available at: https:// ehtrust.org/resources-to-share/printable-resources/ (17.08.2021).

66. Belpomme D., Hardell L., Belyaev I., Burgio E., Carpenter D.O. Thermal and non-thermal health effects of low intensity non-ionizing radiation: An international perspective. Environ. Pollut., 2018, vol. 242, pt. A, pp. 643-658. DOI: 10.1016/j.envpol.2018.07.019

67. Kostoff N., Heroux P., Aschner M., Tsatsakis A. Adverse Effects of 5G mobile networking technology under real-life conditions. Toxicology Letters, 2020, vol. 323, pp. 35-40. DOI: $10.1016 /$ j.toxlet.2020.01.020

68. Russian National Committee of Non-Ionizing Radiation Protection - 2008 report. Available at: https://www.who.int/peh-emf/project/mapnatreps/RUSSIA\%20report\%202008.pdf (11.08.2021).

69. Scientists and Doctors Demand Moratorium on 5G. Increased radiation from cell towers poses potential risks, say scientists from around the world. Environmental Health Trust, 2017. 
Available at: https://ehtrust.org/scientists-and-doctors-demand-moratorium-on-5g-warning-of-healtheffects/ (09.06.2021).

70. The 5G appeal. Available at: https://www.5gappeal.eu/ (09.06.2021).

71. Stop 5G on Earth and in Space: International Appeal, An Emergency Appeal to the World's Governments by Scientists, Doctors, Environmental Organizations and Others. Available at: https://www.5gspaceappeal.org/the-appeal (20.06.2021).

72. El-Hajj A.M., Naous T. Radiation Analysis in a Gradual 5G Network Deployment Strategy. 2020 IEEE 3rd 5G World Forum (5GWF), 2020, pp. 448-453. DOI: 10.1109/5GWF49715.2020.9221314

73. Ishai P.B. The Green Dilemma of $5 \mathrm{G}$ Densification. The Times of Israel. Available at: https://blogs.timesofisrael.com/the-green-dilemma-of-5g-densification/ (19.06.2021).

Stein Y. Preventive measures to reduce harmful effects produced by electromagnetic radiation on health. Health Risk Analysis, 2021, no. 3, pp. 42-52. DOI: 10.21668/health.risk/2021.3.04.eng

Received: 03.06.2021

Accepted: 15.09 .2021

Published: 30.09.2021 